\title{
Study of biological activity of Eruca sativa as antimicrobial agent
}

\author{
Kudair.H. Al_Ameri ${ }^{1}$ \\ Rajaa.K.Baker $^{2}$ \\ K.alameri@yahoo.com \\ Rjaaka1@gmail.com \\ Duaa.A.Al_khusa ${ }^{3}$ \\ Ahmed.M.Al_tememi ${ }^{3}$ \\ Nb81508@gmail.com \\ amnbio86@gamil.com
}

Collage of Ibn Al Haitham for Pure Science

1. Biology Departments.

2. Chemistry Department.

3. Laboratory of Central Service.

Received:- $\quad$ 19/4/2017

Accepted:-11/2/2018

\section{$\underline{\text { Summary }}$}

Keyword: Chemical analysis, Eruca sativa, Bacteria, Fungus.

Chemistry Classifiication QH $301-70505$

The antimicrobial activity of Eruca sativa extract was tested against various Gram-positive and Gramnegative bacteria as well as yeast. Ethanol extract showed better activity against the tested bacteria compared to the yeast. Minimum inhibitory concentration of the extract was $100 \mathrm{gm} / \mathrm{ml}$. Active compounds alkaloid; glycoside, flavonoids and saponins were revealed by the photo chemical analysis. 


\section{$\underline{\text { Introduction }}$}

The use of natural products with therapeutic properties is as ancient as human civilizations about $25 \%$ of the drugs prescribed worldwide still come from plants [1]. The rocket (Eruca sative) commonly found in the mediterrean diet, it's from the family Brassicaceae [2] Eruca sative has positive and beneficial effects on human health because of photochemical it contain [3], Including vitamin A,C,flavonoids and glucoside[4]. Rocket it considered an excellent source of antioxidant [5]. The leaves are used in salad and as a spice, while its seed are used for the production of oil [6]. Eruca seeds and leaves are known for its medicinal properties [7]. Eruca seeds and leaves protected against oxidative damage by increasing the levels of antioxidant enzymes [8]. There are few reports available on antibacterial properties of leaves extracts. Hence this prompted us to screen the leaves extracts. Our works focuses on ethanol extract of Eruca sativa a leaves against bacteria that cause urinary tract infection like E.coli, P.aeruginosa and those are becoming a clinical problem in hospital like S.aureus and determine its active compounds.

\section{Experimental}

Plant: Eruca sativa was collected from Baghdad. The samples were washed, dried then grand to prepare the extract $100 \mathrm{mg} / \mathrm{mL}$ and $300 \mathrm{mg} / \mathrm{mL}$ [9].

\section{Chemical analysis}

\section{Determination of Alkaloi:}

$200 \mathrm{~mL}$ of $10 \%$ acetic acid in ethanol was added to $5 \mathrm{gm}$ of the sample and put into a 250

$\mathrm{mL}$ beaker, covered and allowed to stand for $4 \mathrm{hr}$. This was filtered and the extract was concentrated on a water bath to one-quarter of the original volume. Concentrated ammonium hydroxide was added drop wise to the extract until the precipitation was complete. The whole solution was allowed to settle and the precipitation was collected and washed with dilute ammonium hydroxide and then filtered. The residue is the alkaloid, which was dried and weighed [10, 11, 12].

Determination of saponin: $20 \mathrm{gm}$ of ground sample were put into a conical flask and $100 \mathrm{~cm}^{3}$ of $20 \%$ aqueous ethanol were added. The samples were heated over a hot water bath for $4 \mathrm{hr}$ with continuous stirring at $55^{\circ} \mathrm{C}$. The mixture was filtered and the residue re-extracted with another $200 \mathrm{~mL} \mathrm{20 \%}$ ethanol. The combined extracts were reduced to $40 \mathrm{~mL}$ over water bath at about $90^{\circ} \mathrm{C}$. The concentrate was transferred into a $250 \mathrm{~mL}$ separatory funnel and $20 \mathrm{~mL}$ of diethyl ether was added and shaken vigorously. The aqueous layer was recovered while the ether layer was discarded. The purification process was repeated. $60 \mathrm{~mL}$ of $\mathrm{n}$-butanol was added. The combined $\mathrm{n}$ butanol extracts were washed twice with $10 \mathrm{~mL}$ of $5 \%$ aqueous sodium chloride. The remaining solution was heated in a water bath. After evaporation the samples were dried in the oven to a constant weight; the saponin content was calculated as percentage $[10,11,12]$.

Determination of flavonoid: To determination of flavonoid, $10 \mathrm{gm}$ of the plant sample was extracted repeatedly with $100 \mathrm{ml}$ of $80 \%$ aqueous methanol at room temperature. The whole solution was filtered through whatman filter paper No 42. The filtrate was later transferred into a crucible and evaporated into dryness over a water bath and weighed to constant weight $[10,11,12]$.

Determination of glycosides: The absorbance was measured at $495 \mathrm{~nm}[10,11,12]$, to determination of glycosides. after $10 \%$ of extract were mixed with $10 \mathrm{ml}(95 \mathrm{~mL}$ of $1 \%$ picric acid $+5 \mathrm{~mL}$ of $10 \% \mathrm{NaOH}$ ). After an hour the mixture was diluted with $20 \mathrm{~mL}$ distilled water.

\section{$\underline{\text { Determination of antibacterial activity }}$}

Gram positive bacteria were

Streptococcus pyogenes and Staphylococcus aureus, and Gram negative bacteria were Serratia marcescens, Esherichia coli, Shigella dysenteria, Burkholderia cepacia, Klebsilla pneumonia, 
Pseudomonas earuginosa, Providencia sp and Acinetobacter sp. All were selected for this study from Al-Nahrian medicine collage. Agar well diffusion manner [13] was utilized to appraisal the antibacterial activity of the extract, which incubated at $37^{\circ} \mathrm{C}$ for 24 hours.

\section{The diameter of the zone}

The inhibition zone was measured in millimeter. Minimum inhibitory concentration (MIC) of Eruca sativa leafs was determined by micro titration technique [14].

\section{$\underline{\text { Determination of antifungal activity }}$}

To assess the inhibition activity of the extract against fungi the percussion desorbed by [15] was wielded.

\section{$\underline{\text { Results }}$}

Table (1) showed the antibacterial activity of the ethanol extract at $300 \mathrm{mg} / \mathrm{mL}$. From the result we can see that the highest activity was against

Pseudomonas earuginosa then E.coli, Providencia Sp, Shigeilla dysenteria, Serratia marcescens, and Streptococcus pyogens. Table (2) showed the antifungi activity of the extract at $300 \mathrm{mg} / \mathrm{ml}$ which apper inhibition activity against Candida albicans only. The chemical analyze showed in table (3). Than we compare the antibacterial activity of Eruca extract with antibiotic ciprofloxacin 5ug, ampicilin 10ug, and the result showed in table (4).

\section{$\underline{\text { Discussion }}$}

The use of the medicinal plants in the treatment of human diseases is an age-old practice in traditional systems of medicine throughout the world. Medicinal plants are an important source of diverse bioactive and therapeutic compounds. And the recent increase in the numbers of multidrug-resistant (MDR) bacteria has triggered immense interest in new drugs or preparation from natural sources, including plants. Particularly problematic groups of MDR bacteria include methicillin-resistant Staphylococcus aureus (MRSA), vancomycin-resistant enterococci (VRE), beta-lactamase producing enteric bacteria (E.coli, Salmonella, Klebsiella, Shigella spp.) and other MDR Pseudomonas spp., Campylobacter spp., and Mycobacterium tuberculosis. Excessive and indiscriminate use of antibiotics has led to the development of such drug-resistant bactria both in hospitals and communities all over the world.

Resistance to most commonly used antibiotics, including beta-lactam antibiotics and newer synthetic fast-acting fluoroquinolone, is on the rise. Bacteria develop resistance through various mechanisms, encoded by chromosomes, plasmids, and transposons.

Considerable work has been done on the antibacterial activity of plant extracts and phytocompounds. In some cases the mode of active of phytocompounds has been documented. Considering the various mechanisms of drug resistance present in bacteria, the specific activity of plant extracts/compounds may help in combating MDR bacteria. Such novel activity includes [16] MDR pump inhibition activity, [17] inhibition of beta-lactamase production or activity [18]. Anti-R-plasmid activity (interference with plasmid physiology [19]. Synergy of phytocompounds with antibiotics [20]. Targeting virulence and pathogenicity of bacteria [21]. And gene transfer mechanisms. Some of these approaches have already been attempted by researchers, while other suitable strategies and methods have to be employed by the scientists and pharmaceutical company involved in screening new antimicrobials from medicinal plants. Careful selection of potential medicinal plants and intelligent design of the test systems is the key to successful screening outcome. Because of increasing incidence of multiresistant bacterial infection caused by Gram-positive bacteria (such as Staphylococcus, Enterococcus and Streptococcus species) and Gram-negative bacteria (such as Pseudomonas, Enterobacter) medicinal plant have been used for centuries in folk medicine as remedies for human disease because they content compounds of therapeutic 
value [22]. Alkaloid intercalate into cell wall ahd Baqir. R, K. (2014), Effect of Aqueous Extract of or DNA, flavonoids inactivate enzymes with cell visit vinifera leaf on some Immunoglobulin in wall [23]. Urinary tract infection cause by levothyroxine sodium induced hyper thrioidism Esherichia coli and Pseudomonas earuginosa [24]. Rabbit female ,J, natural. Sc. Research Vol4, No. Candida albicans causes the yeast infection whil(h) Ukiya, M; Akihisa , T; Yasukawa , K; Tokuda , occurs in mouth [25]. H; suzuk , T; (2006). Anti - inflammatiory, Anti -

\section{Conclusion}

The result suggests that the detection ratio of the resistant bacteria become lower so the use of extract could be decreased Urinary tract infection.

\section{References:}

1) Khoobchandani, M.; Ojeswi, B.K.; Ganesh, N.;

, 1989) 92-94

Srivastava, M.M.; Gabbanini, S.; Matera, Iori,) Roopashree, T.S. Dang, RH.S and Narendra, C. R.R. (2010) and Valgimigli; L. Antimicrobial 2008. Antibacterial activity of antipsoriatic herb. properties and analytical profile of traditional Int. J. of Applied Research in Natural products. Eruca sativa seed oil; comparison with various Vol (3) pp20-28

aerial and root plant extracts. Food chem. 120:2147) Eloff, T.N. (1998). Asensitive and quick 224.

2) Simoes, M.; Bennet, R.N. and Rosa, (2009) E.A.S Simitory concentration of plant extract for Understanding antimicrobial activites of bacteria. Plant Med. 64: 711-713.

phytochemicals against multidrug resistą5) Ehang, S.T.; Wang, S.Y.; Clwu; Chen, P.F.; Kuo, bacteria and biofilms. Natural Product Reports, Y.H. and Holzforschung. (2000). 54, pp 241-245. 26(6): 746-757.

16) WHO. TB: A Global Emergency (1994). WHO

3) Yaniv, Z; Schafferman, D. and Amar, Z (1998). report on the TB Epidemic. World Health Tradition uses and biodiversity of rocket (Eruca Organization, Geneva.

Sativa) Econ. Bot. 52: 394-400.

17) Tait, S. J. Med. Microbial. (1993), 83, 157-159.

4) Martinez- Sanchez, A.; Gil-Izquierdo, A.; Gil,M 1 \&.) Davies, J. Science (1994), 264, 375-382. and errers, F.F. (2008). A comparative study 196$)$ Nikaido, H. J. Bacterial. (1996), 178, 3853-3859. flavonoid compounds, vitamin, and antioxidabt) Paulson, I.T., Brown, M.H>, Skurray, R.A. properties of leaf Brassicaceae species. J. Agric Microbial Rev (1996). Pp 575-608. food Chem. 56: 2330-2340.

21) Goldman, J.d., White, D.G., Levy, S.B. (1996)

5) Hassein, F. T. K, (1985). Medicinal plants in libya. Antimicrob. Agents Chemother 40, 1266-1269. AL-Fath University, Arab Encyclopdia Hous2) Okwu, D.E. and Josiah, C. (2006). Evaluation of Libya, 86-96,1st Ed.

6) Lamy, E. J. Schroder, S. (2008) antigenotoxic properties of Eruca sativa. Food. Chem 46: 2415- 361. 2421.

23) Ryan, K. J. and Ray, C.G. (2004). Sherries

7) Yani V, Z, D. And, Z. (1998) Tradition uses and medical microbiology: Anintroduction of biooliversity of rocket. J. Econom, Bot. 52: 394- infectious diseases, $4^{\text {th }}$ ed, Mc. Graw Hill, New 400.

8) Alam;M.S. and Jabbar, Z. (2007) Eruca satiz) Gptak, Trautner B. (2012). In the Clinic. Urinary seeds possess antioxidant activity. Food chem tract infection. Ann. Intern. Med. Mar. 6:156: 3toxicol. 45: 910-920.
15. 


\section{AL-Qadisiyah Journal of pure Science $\quad$ Vol.23 No.2 $\quad$ Year 2018}

25) Nicolle, L. E. (2008). Uncomplicated urinary tract pyelonephritis. Urollin North. Am 35(1): 1-1 infection in adults including uncomplicated

\begin{tabular}{|c|c|}
\hline Bacterial strains & 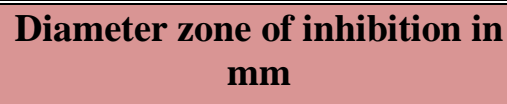 \\
\hline Pseudomonas Earuginosa & 28 \\
\hline Providencia Sp. & 13 \\
\hline Esherichia coli & 13 \\
\hline Streptococcus pyogens & 12 \\
\hline Shigeilla dysenteria & 12 \\
\hline Serratia marcescens & 12 \\
\hline Klebsiella pneumonia & - \\
\hline Burkholderia cepacia & - \\
\hline Acinetobacter Sp. & - \\
\hline Staphylococcus aureus & - \\
\hline Control / DMSO & - \\
\hline
\end{tabular}

Table (1)

Antibacterial activity of Eruca sativa at $300 \mathrm{mg} / \mathrm{mL}$

\begin{tabular}{|c|c|}
\hline Fungi & $\begin{array}{c}\text { Diameter zone of inhibition in } \\
\mathrm{mm}\end{array}$ \\
\hline \hline Candida parapsilosis & - \\
\hline Candida albicans & 18 \\
\hline Candida tropicalis & - \\
\hline Candida glabrata & - \\
\hline
\end{tabular}


Table (2)

Antifungal activity of Eruca sativa at $300 \mathrm{mg} / \mathrm{mL}$

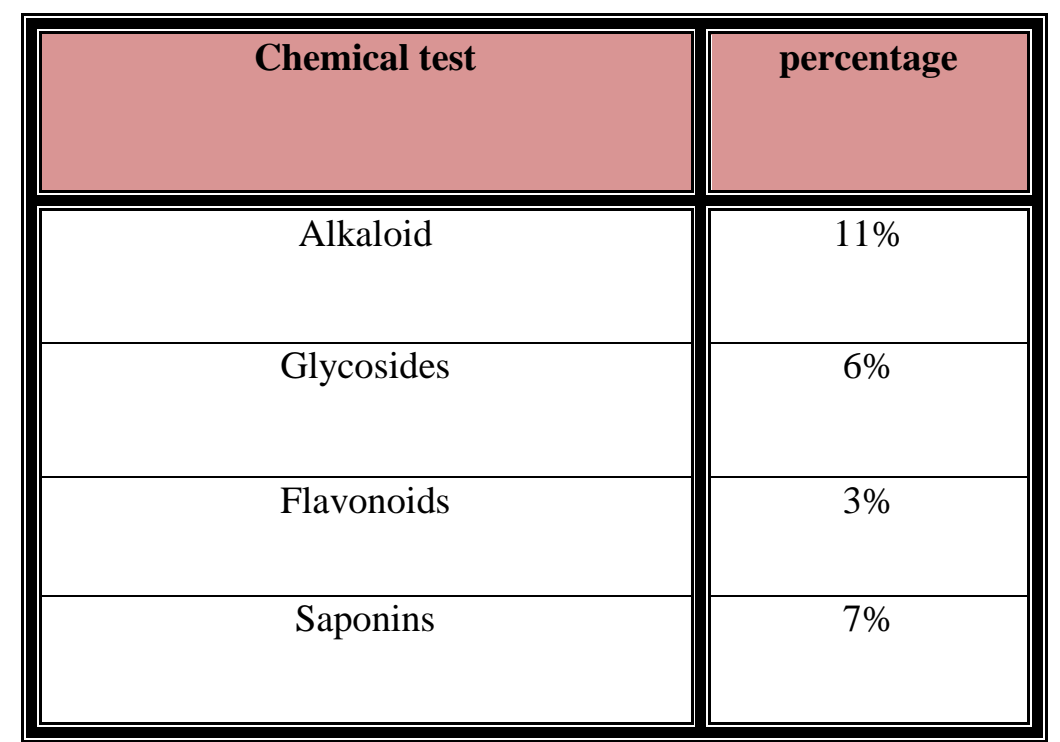

Table (3)

Chemical Anylazes of Eruca sativa extract

\begin{tabular}{|c||c|c||}
\hline \multicolumn{1}{|c||}{ Bacterial strains } & $\begin{array}{c}\text { Diameter zone of } \\
\text { inhibition in mm for } \\
\text { Ciprofloxacin 5ug }\end{array}$ & $\begin{array}{c}\text { Diameter zone of } \\
\text { inhibition in mm for } \\
\text { Ampicillin 10ug }\end{array}$ \\
\hline \hline Klebsiella pneumonia & 22 & 19 \\
\hline Staphylococcus aureus & 19 & 22 \\
\hline Esherichia coli & - & 11 \\
\hline Shigeilla dysenteria & - & - \\
\hline Pseudomonas Earuginosa & & \\
\hline
\end{tabular}

Table (4)

Antibiotic sensitive 

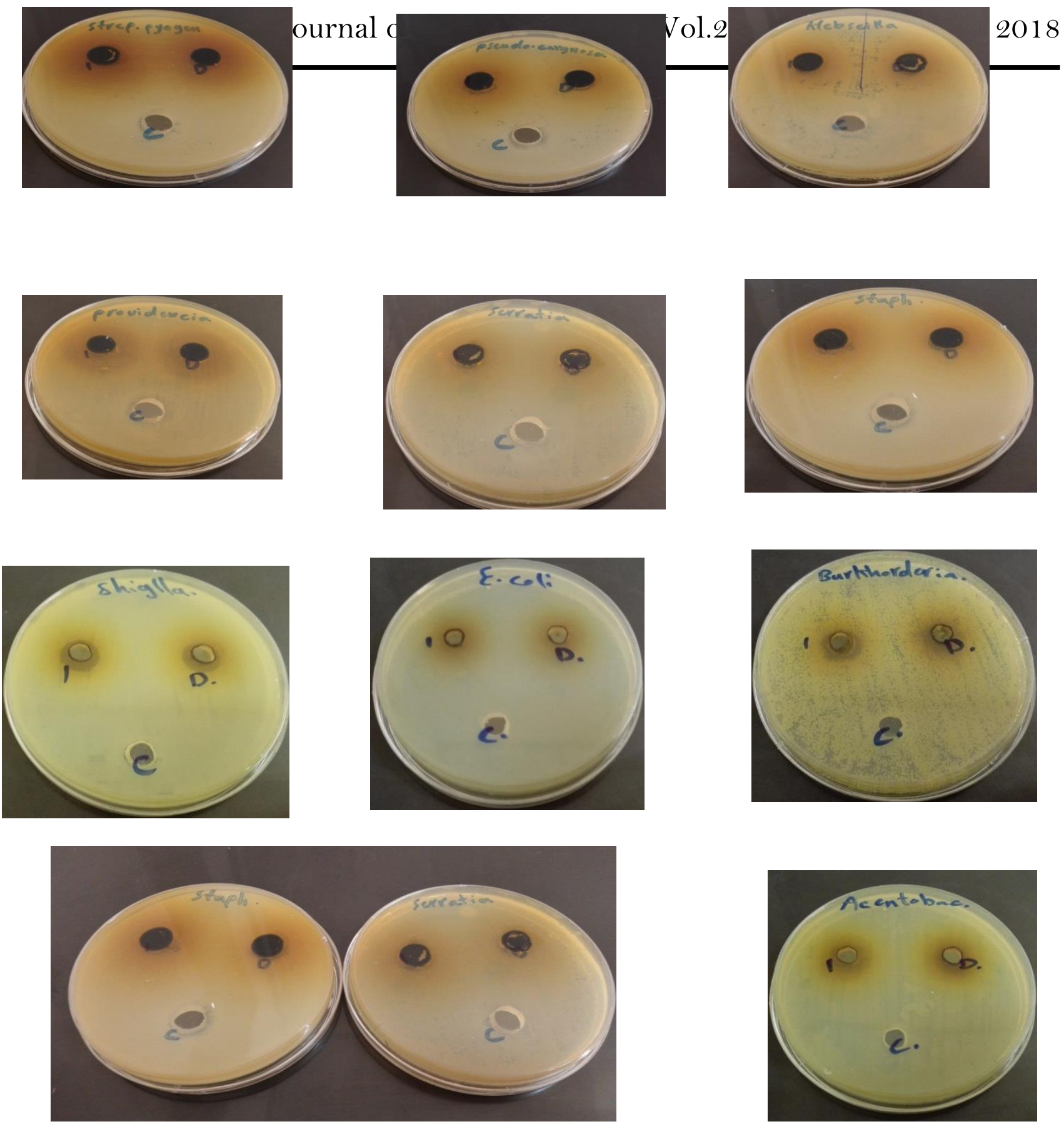
C: control
D: dublicate
1: Extract of Eruca sativa

The result of antibacterial activity of Eruca sativa at $300 \mathrm{mg} / \mathrm{mL}$
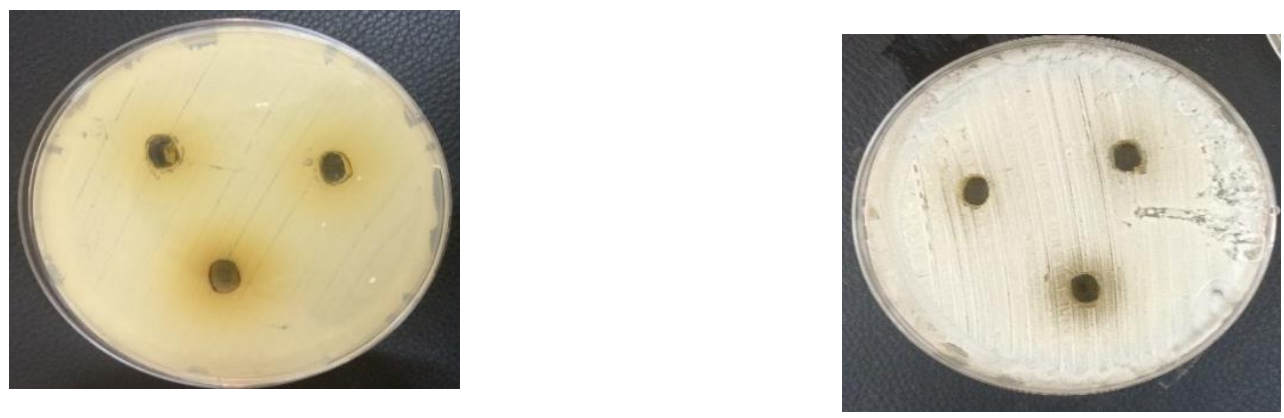
AL-Qadisiyah Journal of pure Science $\quad$ Vol.23 No.2 $\quad$ Year 2018

Candida tropicalis

Candida glabrata

\section{Candida albicans}

Candida parapsilosis

The result of antifungal activity of Eruca sativa at $300 \mathrm{mg} / \mathrm{mL}$
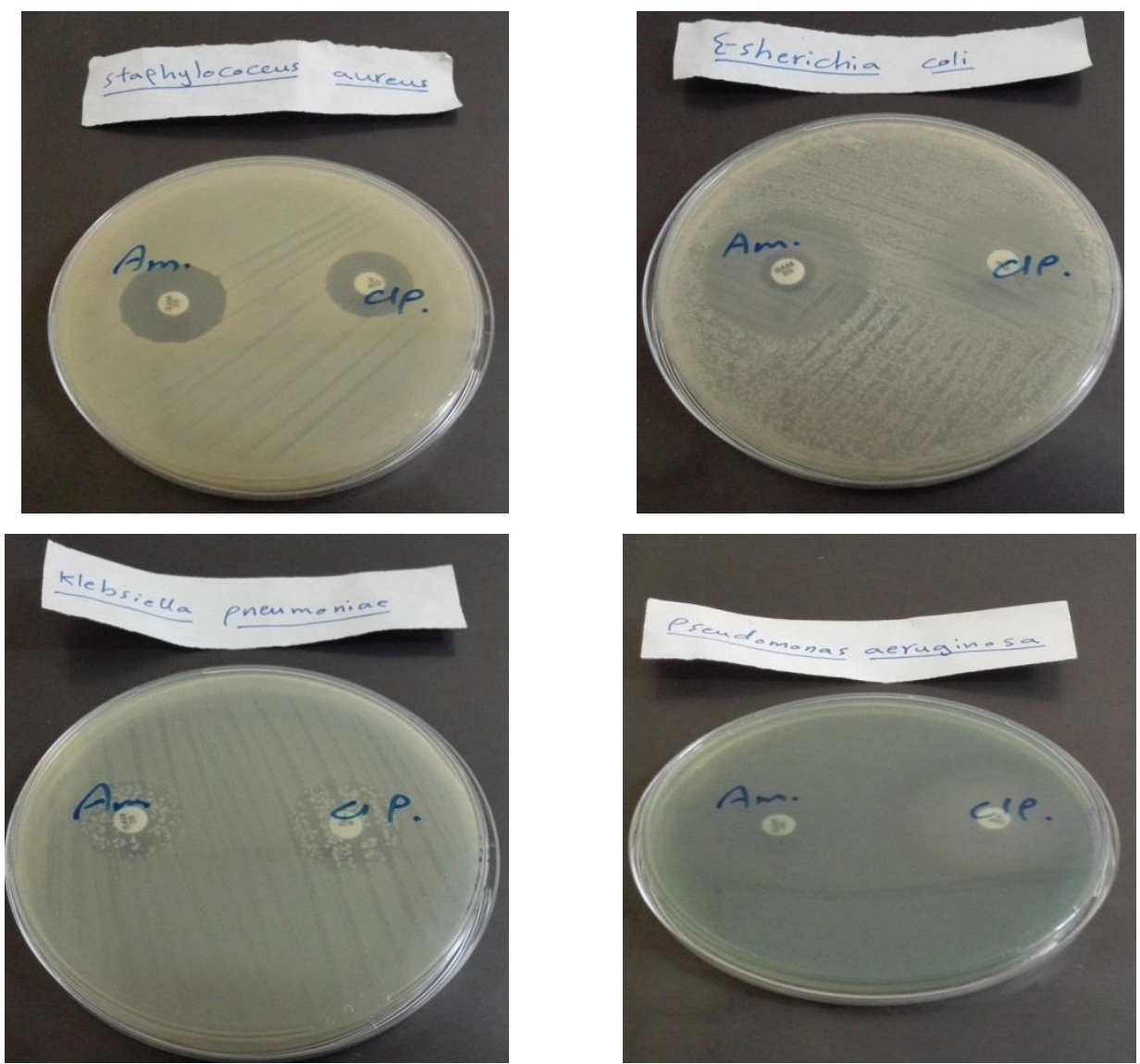

The result of antibiotic sensitive 